\title{
Correction to: 75th Foundation Day of CSIR-National Physical Laboratory: Celebration of Achievements in Metrology for National Growth
}

\author{
S. Yadav, G. Mandal* (1), V. K. Jaiswal, D. D. Shivagan and D. K. Aswal \\ CSIR - National Physical Laboratory, Dr. K. S. Krishnan Marg, New Delhi 110012, India \\ Published online: 17 June 2021 \\ (C) Metrology Society of India 2021
}

Correction to: MAPAN-Journal of Metrology Society

of India (March 2021) 36(1):1-32

https://doi.org/10.1007/s12647-021-00442-4

Page 6, caption of Fig. 2 may be read as:

"The Gazette notifications of Legal Metrology (National Standards) Rules, 2011 about CSIR-NPL as keeper of the measurement standards and Ministry of Environment, Forest and Climate Change notifying CSIR-NPL as National verification agency for emission and ambient air monitoring instruments".

Publisher's Note Springer Nature remains neutral with regard to jurisdictional claims in published maps and institutional affiliations.

The original article can be found online at https://doi.org/10.1007/s12647-021-00442-4.

*Corresponding author, E-mail: goutam@nplindia.org 